\title{
釜石鉱山における銅鉱選鉱場の操業について
}

正会員石原弘明*

\section{Operation of Copper Flotation Plant at the Kamaishi Iron Mine}

Hiroaki. ISHIHARA

We had treated only tailings from magnetic separation of iron ore in the copper flotation plant till 1950. Then, according to the development of copper deposits, two plants for copper ores were constructed. One is a small plant which has a capacity of 150 tons per day, and the other is a plant which has a capacity of 600 tons per day.

There are two kinds of copper deposits at the Kamaishi mine.

(1) The lst. deposit of copper ore:

low grade magnetite ore containing copper ore, average grade : $25 \% \mathrm{Fe}, 0.6 \% \mathrm{Cu}$

(2) The 2nd. deposit of copper ore: mixed ores of chalcopyrite, pyrrhotite, and magnetite, average grade: $18 \% \mathrm{Fe}, 1.5 \% \mathrm{Cu}$

Ores from the lst. deposit are treated in 600 tons plant, and ores from the 2nd. are treated in 150 tons plant. In the latter plant, products of ball mill are treated with 750 unit flotation cell, and about $70 \%$ of copper contents are recovered here. And then sinks are sent to ball mill of the plant treating tailings of iron magnetic separation plant. In the former plant, copper minerals and iron minerals are recovered step by step by the way of flotation and magnetic separation alternately.

\section{1. 概 要}

釜石鉱山における銅鉣の選鉱は，大別乙て鉄磁選工場 よりの尾鉱妈理系統と，坑内より銅鉱として採掘される 銅原鉣を処理する系統とより成つている。前者は以前よ り操業して来た選鉱場であつて，鉄尾鉣中の粉鉱の部分 る処理している。後者の鉱床は炤和 25 年上り開発された ものである。本報告においてはこの新しい銅原鉱専用の プラントについて, 現在の操業状況及び今後の計画に関 して概要を述へよう。

銅選鉱場というもののあくまで鉄鉱床の周辺に存在す る銅鉣石の処理であるため，原鉱には必ず鉄鉱が伴つて くる。したがつて磁選機による鉄回収が併用される。

\section{2. 銅 鉱 石}

現在銅鉱石として採掘しているのはいわゆる第一鉱床 の鉣石約 $540 t /$ 日と，いわゆ第二鉣床の鈗石約 130t/日 合計約 $670 t /$ 日 である。第一鉝床とは含銅低品位磁鉄鉣 の鉱床で，以前よりその存在は大略判明していたけれ ぞ，鉄銅共に低品位のために，稼行価值がないとして開 発されなかつたものである。昭和 24 年から始められた本 格的の銅鉱調查により，その鉱量の大なることと，銅鉄

* 日鉄鉱業株式会社釜石鉱業所選鉱課浮選係長
両方交選別採取することによる稼行価值の上昇とによつ て脚光を浴びるに至つたもので，現在判明している範囲 内に抢ける平均品位は鉄約 $25 \%$, 銅約 $0.6 \%$ 程度であ る。第二鉣床とは黄銅鈜及び竝硫鉄鉣を主体とする鉣床 で,これに若干の磁鉄鉱を伴つている。平均品位は銅約 $1.5 \%$ ，鉄約 $18 \%$ (この中約 $5 \%$ \%は造岩鉱物中の鉄量で ある故，鉱石よりの品位は $13 \%$ 程度）である。両鉣床の 鉣石の完全分析を第 1 表に示京。

第1表 完全分析表

\begin{tabular}{|c|c|c|c|c|c|c|c|c|c|}
\hline & $\mathrm{Fe}$ & $\mathrm{SiO}_{2}$ & $\mathrm{Mn}$ & $P$ & $\mathrm{~S}$ & $\mathrm{Cu}$ & $\mathrm{Al}_{2} \mathrm{O}_{3}$ & $\mathrm{CaO}$ & $\mathrm{MgO}$ \\
\hline & 27.40 & 25.59 & 0.302 & 0.055 & 1.50 & 0.817 & 7.54 & 19.07 & 18.18 \\
\hline $50 t)$ & 19.14 & 29.89 & 0.403 & 0.045 & 3.45 & 1.34 & 5.17 & 23.74 & 23.05 \\
\hline 考精 & 32.42 & 7.99 & 0.094 & 0.024 & 27.60 & 16.97 & 1.76 & 5.56 & 0.820 \\
\hline
\end{tabular}

\section{3. 選 鉱 系 統}

150 七プラント及び600 1 図及び第2 図の如くなる。しかして圀中の主要機械一 覽表は第 1困附表及び第 2 附表に示す。

\section{150 tプラント}

$150 \mathrm{t}$ プラントは第一鉣床及び第二鉣床を開発するに 当り，その開発によつて生ずる鉣石ち好理すると同時に 


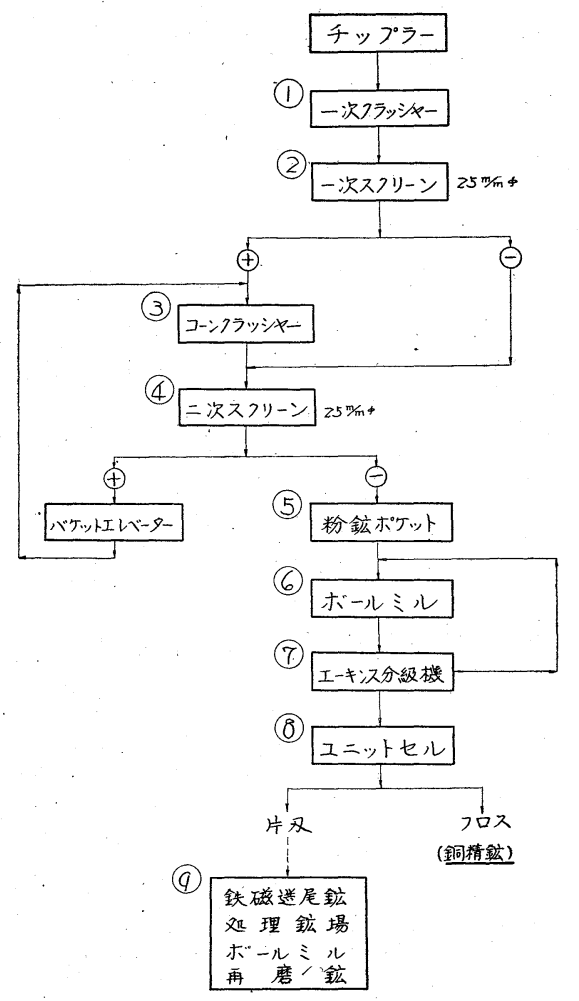

第1図 $150 t$ プラント系統図个

第 2 図 $600 t$ プラント系統図 $\rightarrow$

第1図附表

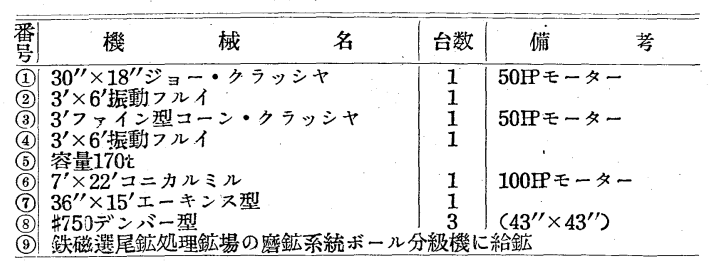

第 2 図 附

\begin{tabular}{|c|c|c|c|}
\hline 番 & 械 & 台数 & 考 \\
\hline 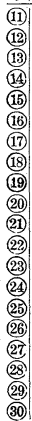 & 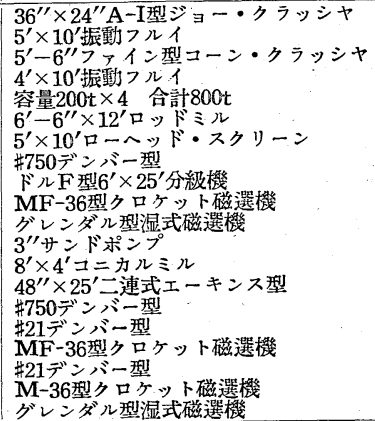 & \begin{tabular}{|c|}
1 \\
1 \\
1 \\
2 \\
1 \\
1 \\
3 \\
1 \\
1 \\
2 \\
2 \\
1 \\
1 \\
2 \\
6 \\
1 \\
$16 \times 2$ \\
2 \\
2 \\
2
\end{tabular} & 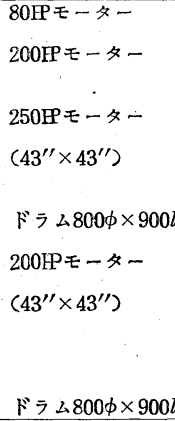 \\
\hline
\end{tabular}

パイロットプラントを兼ねて，炤和25年より26年にかけ
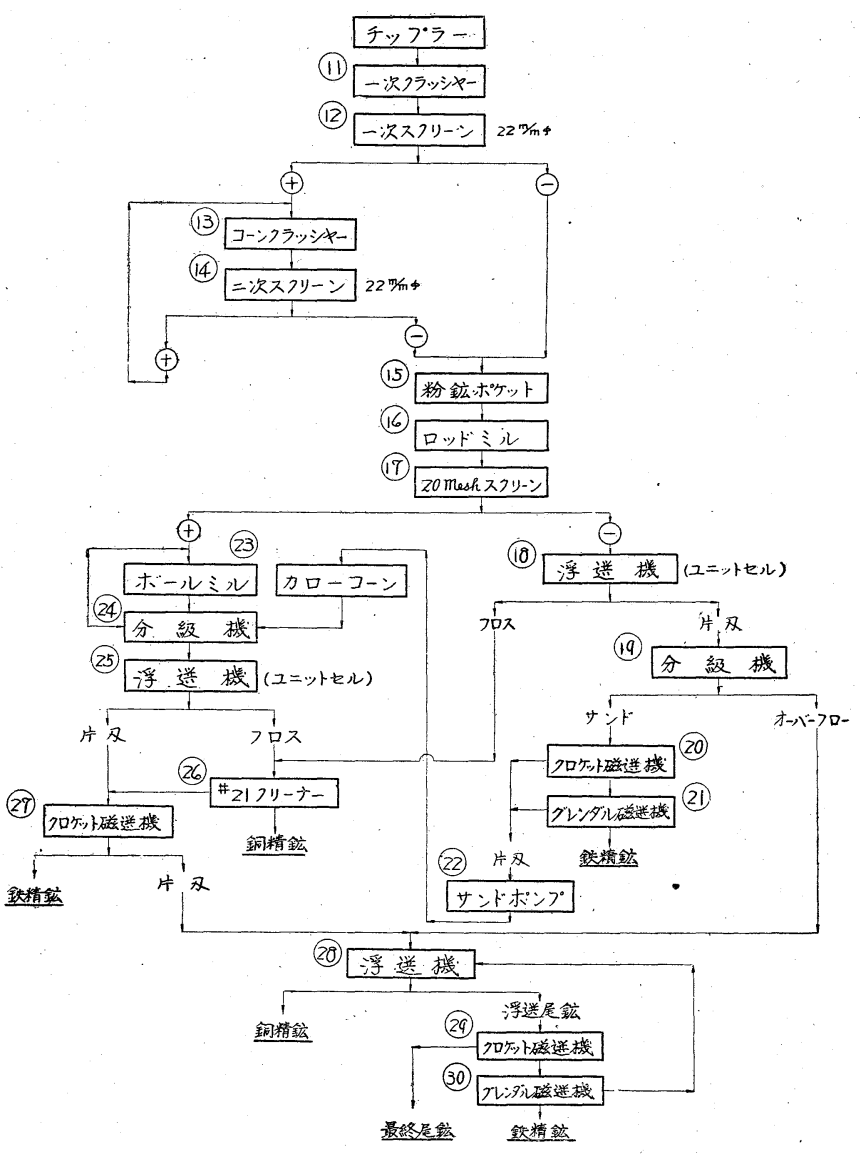

て建設した工場である。現在は前にも述べた如く，第二 鉱床の高品位銅鉱石を専門: 二処理している。

本工場は完全なプラントではなく，磨鉣後に 3 台の二 ニットセルによつて粗選を行うまでの系統を有するに過 ぎず，粗選後は鉄磁選工場尾鉱処理系の磨鉱回路に送鉣 して再処理するようになつている。

\section{1 破 碎 系}

坑内よりの粗鉱（粒度 $300 \mathrm{~mm}$ ) 夿ボールミル給鉱の $25 \mathrm{~mm}$ に砕くのに，二段破砕を行つている。すなわち一 次クラッシヤとして $30^{\prime \prime} \times 18^{\prime \prime}$ ブレーク・クラッシャ, 二次クラッシャとして $3 \mathrm{ft}$ ファイン型コーン・クラッシ ヤを使用している。二次クラッシヤは振動フルイと閉回 路をなしすべて $25 \mathrm{~mm} 以 下 に$ 砕いてしまう。妈理容量は 大体 $30 \mathrm{t} / \mathrm{h}$ である。

\section{2 磨鉱及びユニットセル系}

磨鉣は $7^{\prime} \times 22^{\prime \prime}$ ニニカルボールミルと $3.6^{\prime \prime}$ エーキン 不型分級機之の閉回路より成り，粒度は 35 mesh 在基 準としている。産物は $\$ 750$ デンバー型ニニットセル 3 台によつて粗選して銅精鉣を採り，原鉣品位 $1.5 \% \mathrm{Cu}$ を $0.4 \% \mathrm{Cu}$ 程度にまで下げて鉄磁選工場入送る。 
ここにニニットセルを設置したのはこの系統よりの 鈗石は後で低品位の鉄磁選尾鉣 $(0.3 \sim 0.35 \% \mathrm{Cu})$ と混 合処理される故，高品位の先まで送ることは非常に不利 であり、しかして完備した浮選系統を婹置することは， 場所的にもまた細磨鉱による処理量の減少からも條件が 悪く，望ましくない。以上の理由により最少限度の穖械 配置として，操業的には磨鉱系に含めてニニットセルを 設置したのである。

\section{5. $600 t$ プラント}

600 七プラントは第一鉱床の含銅低品位磁鉄鉣孛処理 するために設計し，昭和28年より29年にかけて建設した 選鉱場である。その後の鉣量増加により現在 $1,000 \mathrm{t} フ ゚$ ラントへの拡張を計画中である。

本選鉣場は銅・鉄を如何にして有利に回収するかに留 意し，大体次の点を設訫の起点とした。

(1) 磁鉄鉣は大体 $20 \mathrm{mesh}$ 附近で単体分離する。

（2）硫化鉣物は $65 \mathrm{mesh}$ 附近で単体分離する。乙か 乙て硫化物相互間すなわち黄銅鉝之硫化鉄との単体分離 は150mesh 附近である。

（3）鉄精鉣 (磁鉄鉱) 中の含銅量は $0.1 \%$ 以下とす る。

（4）銅と硫化鉄との優先浮選は行わない。銅精鉱は 硫化鉄との混合精鉱として回収し，銅品位を $15 \%$ 以上と する。

以上の点より磨鉱系は二段とし，一次にロッドミル， 二次にボールミルを使用することにした。しかして磨鉱 及び選別系統の大要を次の如くに定めた。

[一次磨鉣 $\rightarrow$ 浮選 $\rightarrow$ 磁選 $\rightarrow$ 二次磨鉱 $\rightarrow$ 浮選 $\rightarrow$ 磁選]

系続別の概要を述べれば次の通りである。

\section{1 破 碎 系}

破砕は一次クラッシャに $36^{\prime \prime} \times 24^{\prime \prime} \mathrm{A}-\mathrm{I}$ 型ジョー・ク ラッシャを，二次に $5^{\prime}-6^{\prime \prime}$ コーン・クラッシャを設置 している。二次コーン・クラッシヤは $4^{\prime} \times 10^{\prime}$ タイロッ ク・スクリーン 2 台と閉回路をなし， $22 \mathrm{~mm}$ 以下に研い て粉鈗ビンに䝪鉱している。

\section{2 磨 鉱 系}

㮝鉣は上述の如く二段磨鉱とし，一次と二㳄の間で 20mesh のスクッーンでフルイ分して，絧下はニニット セル及びクロケッ下磁選機にかけ，それぞれ銅及び鉄を 回収する。網上は更に二次磨鉱系統に送り，その産物は 二次のニニットセル反びクロケッ下磁選機により，再び 銅鉄を回収する。この系統が当プラントの主要部であ り，主浮選系統に送る給鉱を $0.4 \sim 0.5 \% \mathrm{Cu}, 10 \sim 13 \% \mathrm{Fe}$ 程度のものとしている。

\section{3 主浮選系及び鉄回收}

主浮選系は \#21 デンバー型浮選機16槽 2 列の配置であ
り，現在尾鉣品位を $0.07 \% \mathrm{Cu}$ としている。浮選は簡単 な単一浮選であり，使用試薬は起泡㓮には高砂 2 号，捕 収剂には土チル・ザンセート・ソーダを使用している。 浮選尾鉱は再び最終的にクロケッ下磁選機で処理して鉄 鉣を回収し，最終尾鉱として品位 $0.07 \% \mathrm{Cu} ， 9 \% \mathrm{Fe}$ 程 度のもの学排出している。

\section{6. 廃 㵏 処 理}

浮選工場としては上述の $150 \mathrm{t}$ 及び $600 \mathrm{t}$ の他に鉄磁 選工場の尾鉱処理系統の分として約 450t/日 の鉱量を処 理しているから，浮選に抢ける全処理量は 1,100〜1,200 t/日となる。これから生ずる浮選尾鉱の量は 950～1,000 t/日程度であり，これに加うるに鉄選鉣場より出る塊鉱 硑が約 500t/日 ある。

浮選工場よりの尾釷は昭和 30 年 3 月までは脱水機によ り脱水乙て，平均水分 $20 \%$ のケークとして堆積場に廃董 していた。選鉱場の新設及び拡張計画に伴う一連の綜合 計画により，堆積場のがム建設が誩画され，これにより 浮選尾鉱はパルプのままポシプアップすることと決定し， マッドポンプ（パワーポンプ）によるポンどングアップ への切換えとなつた。昭和 30 年 4 月よりこの操業に入 り，順調に予想以上の好成績をあげている。

また鉄選鉱場よりの塊硑はコンぶヤにより運ぱれ，ダ

第 2 表ノ1 選鈗成 績 表 昭和29年度における実績より，25日/月操業さす

\begin{tabular}{|c|c|c|c|c|c|c|c|c|}
\hline & & & \multicolumn{3}{|c|}{$600^{\circ}$ プラント } & \multicolumn{3}{|c|}{$150 t$ プラント } \\
\hline & & & \multirow{2}{*}{ 鉱量t $/$ 月 } & \multicolumn{2}{|l|}{ 品 } & \multirow{2}{*}{ 鉱量 $\mathrm{t}$ /月 } & \multicolumn{2}{|l|}{ 品 } \\
\hline & & & & $\mathrm{Cu}$ & $\mathrm{Fe}$ & & $\mathrm{Cu}$ & $\mathrm{Fe}$ \\
\hline $\begin{array}{l}\text { 原 } \\
\text { 銅 } \\
\text { 鉄 } \\
\end{array}$ & $\begin{array}{l}\text { 鉱 } \\
\text { 精 } \\
\text { 精 } \\
\text { 鉱 } \\
\end{array}$ & 鉱 & \begin{tabular}{|r|}
11,800 \\
553 \\
2,900 \\
8,347 \\
\end{tabular} & \begin{tabular}{r|}
0.90 \\
17.00 \\
0.11 \\
0.10
\end{tabular} & $\begin{array}{l}24.50 \\
31.50 \\
60.90 \\
10.60\end{array}$ & $\begin{array}{r}3,750 \\
275 \\
- \\
-\end{array}$ & $\begin{array}{r}1.33 \\
17.00 \\
0.11 \\
0.08 \\
\end{array}$ & $\begin{array}{r}13.00 \\
31.50 \\
60.90 \\
8.80 \\
\end{array}$ \\
\hline 実收 & 率 & . & & $\begin{array}{r}88.5 \\
6\end{array}$ & & ·鋮 & 93. & \\
\hline
\end{tabular}

第 2 表ノ 2 選鈗成 績表 昭和30年度に㧅引る実績より，25日/月操業さす

\begin{tabular}{|c|c|c|c|c|c|c|}
\hline & \multicolumn{3}{|c|}{$600 t$ プラント } & \multicolumn{3}{|c|}{$150 t$ プラント } \\
\hline & \multirow{2}{*}{ 鉱量 $\mathrm{t} /$ 月 } & 品 & 位 & \multirow{2}{*}{ 鉱量 $\mathrm{t} /$ 月 } & \multicolumn{2}{|l|}{ 品 } \\
\hline & & $\mathrm{Cu}$ & $\mathrm{Fe}$ & & $\mathrm{Cu}$ & $\mathrm{Fe}$ \\
\hline 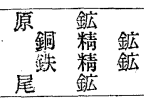 & $\begin{array}{r}13,200 \\
465 \\
2,600 \\
10,235 \\
\end{array}$ & $\begin{array}{r}0.60 \\
15.60 \\
0.09 \\
0.05\end{array}$ & $\begin{array}{r}21.70 \\
31.40 \\
58.10 \\
9.70\end{array}$ & $\begin{array}{r}2,750 \\
252 \\
- \\
-\end{array}$ & $\begin{array}{r}1.48 \\
15.60 \\
0.09 \\
0.05\end{array}$ & $\begin{array}{l}10.90 \\
31.40 \\
58.10 \\
7.70\end{array}$ \\
\hline 実收率 & & 91. & & & $96 \%$ & \\
\hline
\end{tabular}

第 3 表 ボール及び試薬消費量

数字はいすれも $\mathrm{g} / \mathrm{t}$ 学示す

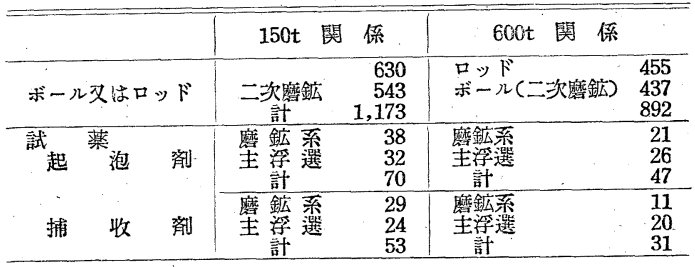


第 4 表ノ1 $150 \mathrm{t}$ 関係主要粒度調心゙例

\begin{tabular}{|c|c|c|c|c|c|c|c|}
\hline \multirow[b]{2}{*}{ サ } & \multirow[b]{2}{*}{ イ ズ } & \multicolumn{2}{|c|}{ ボールミル給鉱 } & \multicolumn{2}{|c|}{ ボールミル排鉣 } & \multicolumn{2}{|c|}{$\begin{array}{l}\text { 分 級 機 溢 } \\
(\text { 流 } \\
(\text { 給鉱 }\end{array}$} \\
\hline & & wt\% & $\Sigma$ & wt\% & $\Sigma$ & wt $\%$ & $\Sigma$ \\
\hline & $\begin{array}{l}+15 \mathrm{~mm} \\
+10 \\
+\quad 6 \\
+\quad 6 \mathrm{mesh} \\
+14 \\
+\quad 28 \\
+\quad 68 \\
+100 \\
+200 \\
+200\end{array}$ & $\begin{array}{r}10.05 \\
23.56 \\
10.16 \\
18.32 \\
12.78 \\
6.07 \\
5.24 \\
\\
13.82\end{array}$ & $\begin{array}{r}33.61 \\
43.77 \\
62.09 \\
74.87 \\
80.94 \\
86.18 \\
100.00\end{array}$ & $\begin{array}{r}5.15 \\
11.34 \\
18.04 \\
7.73 \\
8.25 \\
17.52 \\
31.97\end{array}$ & $\begin{array}{r}16.49 \\
34.53 \\
42.26 \\
50.51 \\
68.03 \\
100.00\end{array}$ & $\begin{array}{r}7.07 \\
19.70 \\
9.60 \\
5.05 \\
23.73 \\
34.85\end{array}$ & $\begin{array}{r}26.77 \\
36.37 \\
41.42 \\
65.15 \\
100.00 \\
\end{array}$ \\
\hline
\end{tabular}

第4表/2600t 関係主要粒度調べ例

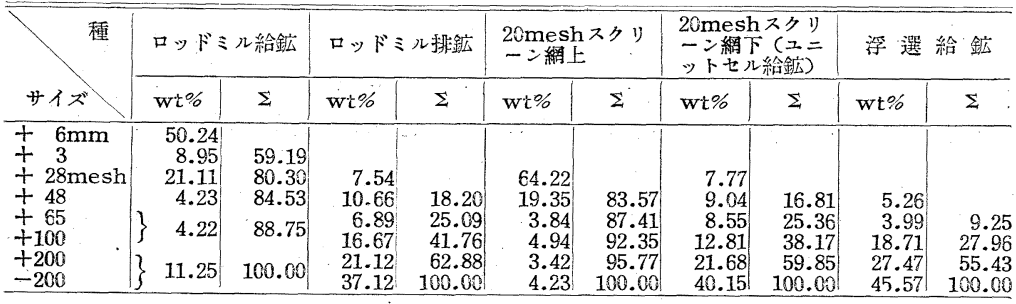

第5表 ノ $150 \mathrm{t}$ ニニット七ル浮選状況例

各データは1䢙間〜1カ月の平均值

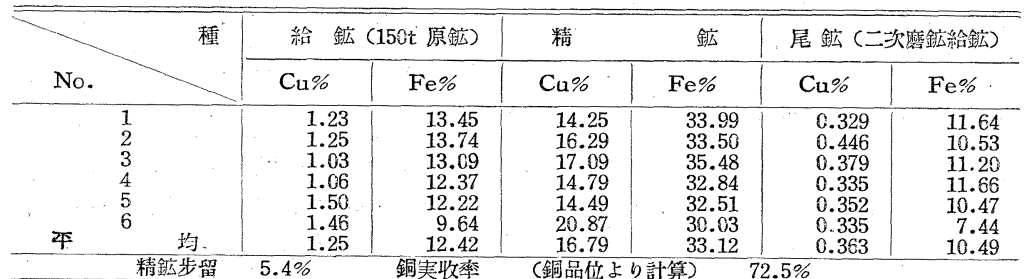

第 5 表ノ2600t ユニットセル浮選状況例

\begin{tabular}{|c|c|c|c|c|c|c|c|c|c|c|}
\hline \multicolumn{11}{|c|}{ 各データは $2 \sim 6$ 日の年均值 } \\
\hline 種 & \multirow{2}{*}{ 原 } & \multirow{2}{*}{ 鉱 } & \multicolumn{4}{|c|}{ 一次ユニットセル(ロッドミル前) } & \multicolumn{4}{|c|}{ 二次ユニットセル(ボールミル前) } \\
\hline \multirow[b]{2}{*}{ No, } & & & 精 & 鉱 & 尾 鉱 & (片及) & 精 & 鉱 & 尾鉱 & 片及 \\
\hline & $\mathrm{Fe} \%$ & $\mathrm{C}_{11} \%$ & $\mathrm{Fe} \%$ & $\mathrm{Cu} \%$ & $\mathrm{Fe} \%$ & $\mathrm{Cu} \%$ & $\mathrm{Fe} \%$ & $\mathrm{Cu} \%$ & $\mathrm{Fe} \%$ & $\mathrm{Cu} \%$ \\
\hline $\begin{array}{r}1 \\
2 \\
3 \\
4 \\
5 \\
6 \\
11 \\
12 \\
13 \\
13 \\
14 \\
15 \\
16 \\
1 \sim 6 \text { 平均 } \\
11 \sim 16 \text { 年均 }\end{array}$ & $\begin{array}{l}21.57 \\
23.07 \\
21.33 \\
24.81 \\
18.54 \\
23.59 \\
20.29 \\
21.70 \\
24.34 \\
22.76 \\
24.34 \\
23.46 \\
22.15 \\
22.81\end{array}$ & $\begin{array}{l}0.844 \\
0.778 \\
0.906 \\
0.868 \\
0.663 \\
0.642 \\
0.893 \\
0.770 \\
0.678 \\
0.770 \\
0.847 \\
0.755 \\
0.78 \\
0.78\end{array}$ & $\begin{array}{l}28.07 \\
28.91 \\
28.73 \\
27.25 \\
29.86 \\
27.44\end{array}$ & $\begin{array}{l}14.14 \\
18.01 \\
18.96 \\
16.80 \\
15.75 \\
16.40\end{array}$ & $\begin{array}{l}20.07 \\
22.49 \\
20.25 \\
23.72 \\
18.34 \\
22.38\end{array}$ & $\begin{array}{l}0.410 \\
0.380 \\
0.433 \\
0.449 \\
0.442 \\
0.405\end{array}$ & $\begin{array}{l}28.96 \\
26.99 \\
30.82 \\
25.82 \\
29.82 \\
30.34 \\
28.79\end{array}$ & $\begin{array}{l}20.72 \\
14.03 \\
22.00 \\
15.93 \\
12.06 \\
21.82 \\
17.76\end{array}$ & $\begin{array}{l}14.34 \\
21.28 \\
18.05 \\
21.23 \\
17.45 \\
19.34\end{array}$ & $\begin{array}{l}0.432 \\
0.475 \\
0.400 \\
0.416 \\
0.480 \\
0.424 \\
0.44\end{array}$ \\
\hline
\end{tabular}

第6表口ッドミル磨鉱状況試験例

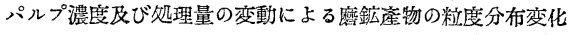

\begin{tabular}{|c|c|c|c|c|c|c|c|c|c|c|c|}
\hline \multirow{2}{*}{$\begin{array}{l}\text { 濃 } \\
\text { 度 }\end{array}$} & \multirow{2}{*}{ サイズ理量 } & \multicolumn{2}{|c|}{$21 t / h$} & \multicolumn{2}{|c|}{$23 t / h$} & \multicolumn{2}{|c|}{$25 t / h$} & \multicolumn{2}{|c|}{$27 \mathrm{t} / \mathrm{h}$} & \multicolumn{2}{|c|}{$29 t / h$} \\
\hline & & $w: t \%$ & $\Sigma$ & wt\% & $\Sigma$ & $w t \%$ & $\Sigma$ & wt $\%$ & $\Sigma$ & wr\% & $\Sigma$ \\
\hline $65 \%$ & $\begin{array}{l}-200 \mathrm{mesh} \\
+200 \\
+65 \\
+20\end{array}$ & $\begin{array}{r}36.45 \\
27.78 \\
31.35 \\
4.42 \\
\end{array}$ & $\begin{array}{r}64.23 \\
95.58 \\
100.00 \\
\end{array}$ & $\begin{array}{r}29.60 \\
34.74 \\
30.92 \\
5.71 \\
\end{array}$ & $\begin{array}{r}63.34 \\
94.26 \\
100.00 \\
\end{array}$ & $\begin{array}{l}28.33 \\
30.73 \\
30.38 \\
10.56 \\
\end{array}$ & $\begin{array}{r}59.06 \\
89.44 \\
100.00 \\
\end{array}$ & $\begin{array}{l}26.76 \\
27.46 \\
28.81 \\
16.97 \\
\end{array}$ & $\begin{array}{r}54.22 \\
83.03 \\
100.00 \\
\end{array}$ & $\begin{array}{l}25.20 \\
25.51 \\
26.40 \\
22.89\end{array}$ & $\begin{array}{r}50.71 \\
77.11 \\
100.00\end{array}$ \\
\hline $75 \%$ & $\begin{array}{l}-200 \\
+200 \\
+65 \\
+\quad 20 \\
\end{array}$ & $\begin{array}{r}26.80 \\
32.05 \\
35.67 \\
5.48 \\
\end{array}$ & $\begin{array}{r}58.85 \\
94.52 \\
100.00 \\
\end{array}$ & $\begin{array}{r}26.87 \\
31.21 \\
33.52 \\
8.40 \\
\end{array}$ & $\begin{array}{r}58.08 \\
91.60 \\
100.00\end{array}$ & $\begin{array}{l}24.17 \\
33.57 \\
30.62 \\
11.64 \\
\end{array}$ & $\begin{array}{r}57.74 \\
88.36 \\
100.00\end{array}$ & $\begin{array}{l}24.68 \\
28.71 \\
32.88 \\
13.73\end{array}$ & $\begin{array}{r}53.39 \\
86.27 \\
100.00 \\
\end{array}$ & $\begin{array}{l}25.72 \\
24.28 \\
28.40 \\
21.00\end{array}$ & $\begin{array}{r}50.60 \\
79.00 \\
100.00\end{array}$ \\
\hline $85 \%$ & $\begin{array}{l}-200 \\
+200 \\
+65 \\
+\quad 20\end{array}$ & $\begin{array}{r}20.02 \\
39.33 \\
33.15 \\
7.50\end{array}$ & $\begin{array}{r}59.35 \\
92.50 \\
100.00\end{array}$ & $\begin{array}{l}27.42 \\
30.65 \\
31.81 \\
10.12\end{array}$ & $\begin{array}{r}58.07 \\
89.88 \\
100.00 \\
\end{array}$ & $\begin{array}{r}28.60 \\
32.55 \\
30.99 \\
7.86 \\
\end{array}$ & $\begin{array}{r}61.15 \\
92.14 \\
100.00 \\
\end{array}$ & $\begin{array}{l}24.88 \\
33.06 \\
26.29 \\
15.77 \\
\end{array}$ & $\begin{array}{r}57.94 \\
84.23 \\
100.00\end{array}$ & $\begin{array}{l}25.28 \\
26.68 \\
28.07 \\
19.97\end{array}$ & $\begin{array}{r}51.96 \\
80.03 \\
100.00 \\
\end{array}$ \\
\hline
\end{tabular}

\begin{tabular}{c|r|r}
\hline & wt\% & \multicolumn{1}{|c}{$\Sigma$} \\
\hline $10 \mathrm{~mm}$ & 27.20 & \\
6 & 21.63 & 48.83 \\
3 & 10.51 & 59.34 \\
$28 \mathrm{mesh}$ & 20.23 & 79.57 \\
-28 & 20.42 & 100.00 \\
\hline
\end{tabular}

條 件; 給鉣の平均粒度

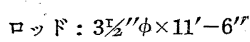

裝入量 : 約 $25 \mathrm{t}$

回転数 : $18 \mathrm{rpm}$
ムの築堤材として使用されてい

\section{7. 操 業成 績}

銅関係の選鉱成績表及び主要 消費表を第 2 表区び第 3 表に示 す。成績表は 29 年度の操業当初 と最近とでは大分原鉣の状況も 変化し，精鉱においても尾鉱に おいても相当変化が見られる 故, 参考弯でに両者を比較表示 した。また処理量は月により操 業日数に差方あるため, 比較上 25日操業に換算して表示した。

第 4 表は磨鉣浮選系の主要部 粒度分布表定示。す600 t 関係 におおてて浮選給鉣とあるのは， 系統困におるて明らかなる如く 二次磨鉱座物々 $\mathrm{F}$ 型分級機オー バーフローとの混合したもので 主浮選機への給鉱である。

第 5 表はユニットセル関係の 浮選状況である。第 4 表と第 5 表とより，異つた條件の下にお。 けるニニットセルの浮選結果の 大要を比較出来ると思う。なお それぞれの浮選條件を比較すれ ば，

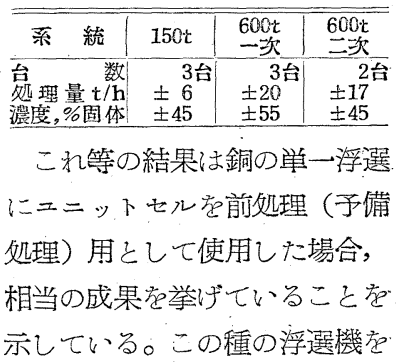


適度に使用し，加適当に配置することにより従来考元 られて来たより遥かに少ない台数の浮選機によって，同 等の成果を得ることが出来るのではないかと思われる。

第 6 表はロッドミルの磨鉱試験の一例を示したもので ある。現在の実操業は処理量は $25 \mathrm{t} / \mathrm{h}$ ，排鉣濃度は $75 \sim$ $80 \%$ ある。濃度が $85 \%$ 或、はこれ以上になると排鉱が 定常流でなく，断続的に多量がぞつと流れ出すため，実 際には操業に困難を来方。

本表に示した結果及びその他現在穼でに行つた種々の 試験結果より見て，次の如き傾问が認められる。

（1）濃度分低心時に処理量の变動に上る産物粒度の 変化が大きく現われる。

（2）処理量が少ない時に，濃度の変化により蓙物粒 度が強く影響される。

(3) 現在行つてい当 20 mesh 磨鉿 ( - 20mesh 90\%) 程度の操業に㧍いては，濃度は比較的高い方が安定した 産物觉得ることが出来る。

\section{8. $1,000 \mathrm{t}$ プラント計画}

600 七プシン下建設当時より予定されていた $1,000 \mathrm{t}$

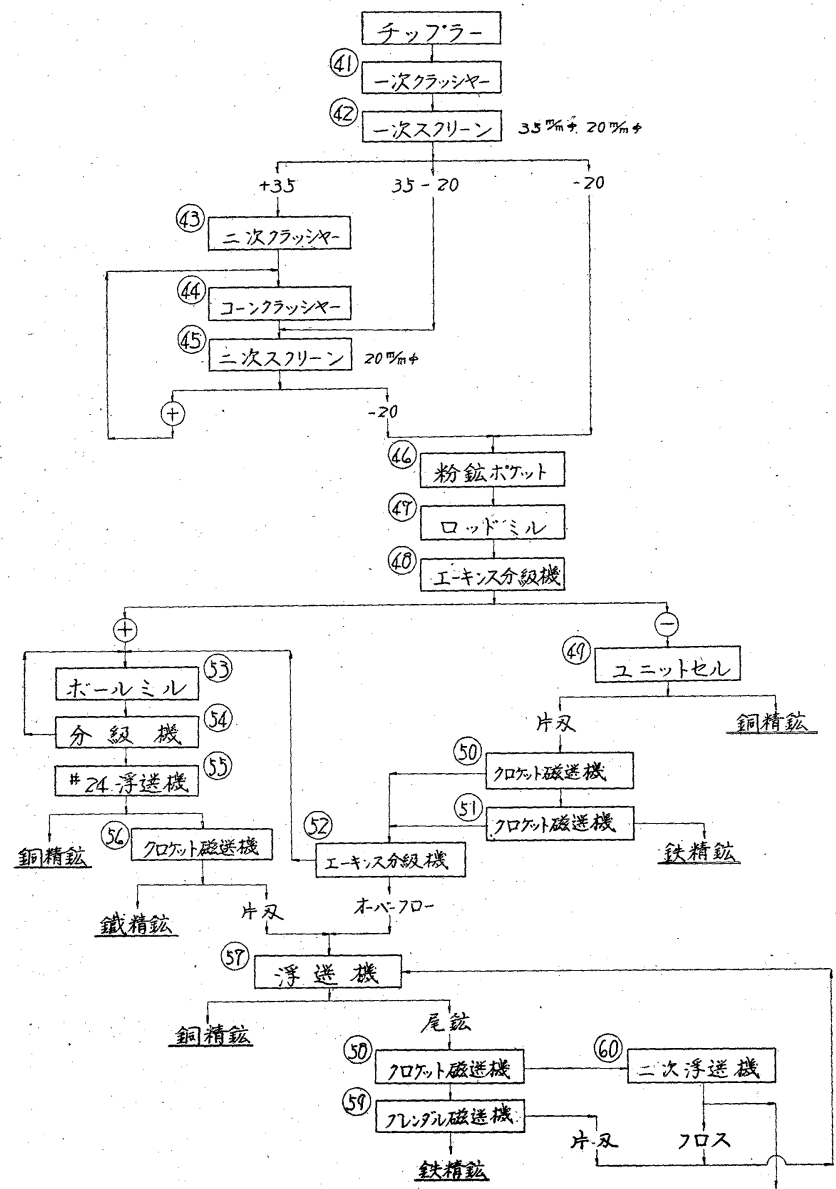

最终尾鈜
ブラントへの拡張工事計画は, 600 t ブシントの寒操業 1 力年余の実績より見て各所に改良を加え，すでに設計 定了乙，明年（31年）4月に完成空期して目下工事施 進めている。その系続図は第 3 図に示してある。改良及 び追加される主なる個所は次の通りである。

\section{1 破 碎 系}

破政系に抢いては一次クシッシャ亡コーン・クラッシ ヤの間に二次クシッシャを大れる。現在のクシッシャは 一次では $400 \mathrm{~mm} \rightarrow 100 \mathrm{~mm}$ で破碎比は約 4 危示し, = ーン・クシッシャでは $100 \mathrm{~mm} \rightarrow 20 \mathrm{~mm}$ で破砕比は約 5 を示している。しかして処理量は 100 t/hでタシッシヤ としてはフルに衝、ている状況である。新唁画では磨鉣 系の負荷の軽减区び処理量の増加在計る之共に，各クラ ッシャの安全率の增加党計るため, 二次クラッシヤとし

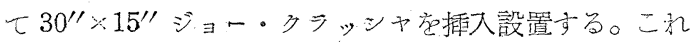
によりミル給鉱粒度は必要により $16 \mathrm{~mm}$ 程度染で細か くすることが出来ると思う。

\section{2 磨鉱 系}

この系統は前にも述ベ通り，当選鉱場の心臓部であ るため慎重な試験の結果学綜合して，相当大巾の改良を 行う計画である。

（1） ロッドミルの処理量堌加のため, 現在 6'-6" 径のもの学 7'径のものとした。ロッド ミルは本プシントの特質の一つであつて，その 磨鉣状況は前述の如く非常に良く，一次磨鉱用 としては優れた結果を示している。

（2）ロッドミル産物のフルイ分は現在ロー ヘッド・スクッーンによつて行つているけれぞ, 網の䒔換更び機械の保持の点より考光て，これ を土ーキンス型分級機に代元分離粒度を現在の 20meshより 35 mesh に下恬る訫画である。

(3) 一次クロケッ市磁選機の精鉣は現在グ レンメ゙ル磁選機により精選しているが，これを

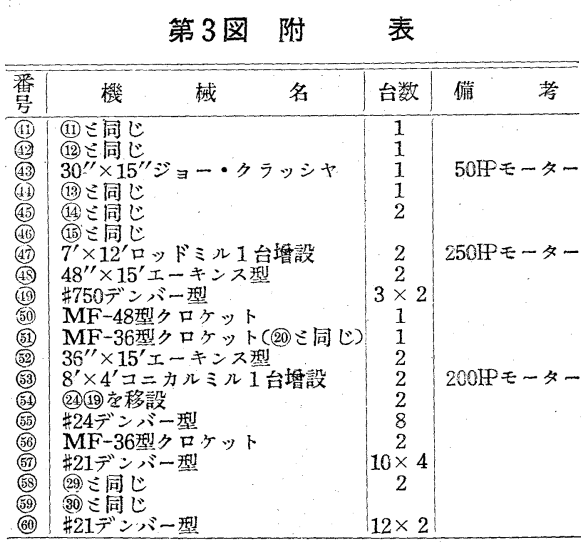

第 3 図 1,000 t プラント搪張計画 系統図（昭和31年 4 月完成予定） 


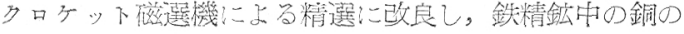

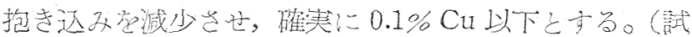

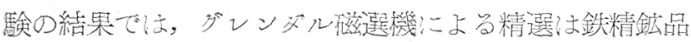

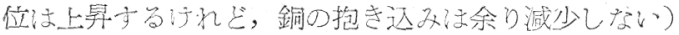

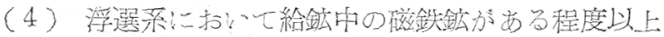
(大体 $15 \% \mathrm{Fe}$ ) になると，浮き加覀々泡立ちる悪々なる

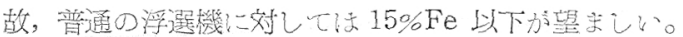

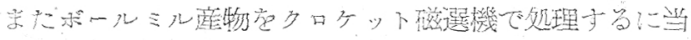

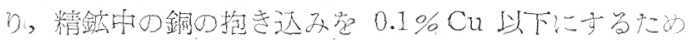

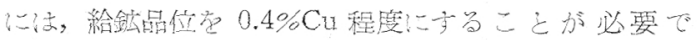

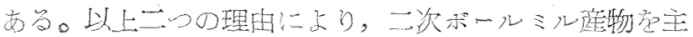

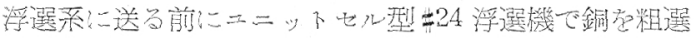

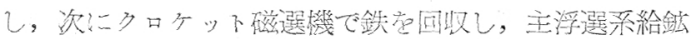

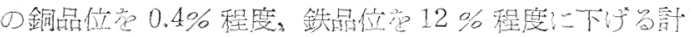
画である。

\section{3 主浮選尒及びその他}

主浮選系蜆在 16 槽 22 列のもの党 10 榑以 4 列々

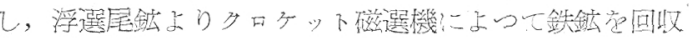

寸当。更に再選用として 8 槽× 2 列起增設し，最終尾銥 品位学 $0.05 \% \mathrm{Cu}$ 以下法さ学手予定である。また精 鈜品位の品質管理更び調整のために，各所上り生产され

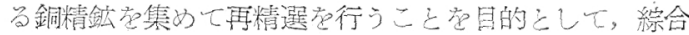
精選穖として8槽危新たに設置する。

\section{9. 結 び}

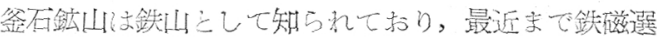

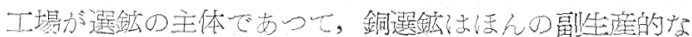
๖の之して考光られ，柴た見られて来た。しか儿現在で

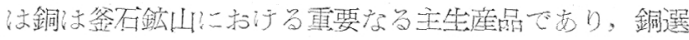
鉱䓪によ鉄部閒に匹敵するものとなつている。

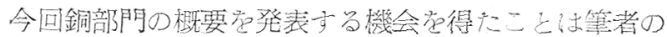
誠に幸いり思う所であ当。な抢本文中!も述心た如く現

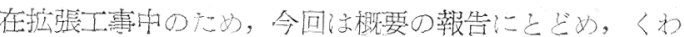
しい報告は1,000 た プシントの完成後に㴛し度いと考元 ている。

\section{製品紹介}

\section{占河のッリッ些ール}

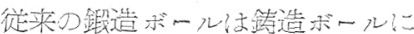

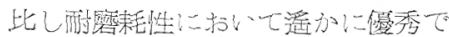

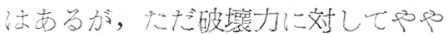
弱以尔点苍持つている。したがつて こうした特性によりコニカルミルは 鋳造ボール灰，マーシーミル，手工

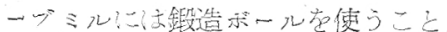
が常識である当れれて来た。

そこで鋳造ボールの耐筫耗性孛生

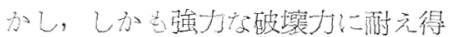

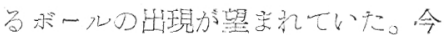
回古河鉣荃では「減らず，割れず，

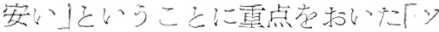
1リドボール教完成さ山た。

\section{○特 徽}

（1）铸造性の困難孛承知で添加 金蠋の工夫起こらしてあるので，磨 耗率汃非常に少なくなつている。

(2) 硬度分布加平均しているの

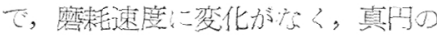

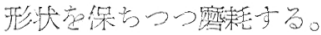

（3）乙たがて、ミル内のボー 心は大ささが裾長となり特に二次磨 鉣仁適士口。

（4）從来の遠鋳造禾ールの上 うな中心紧坊ないので最後衣で廃ボ 一ルが出ない。(写真右参照)

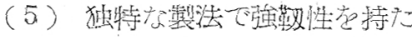
せ七方るので，どんなミル傎用し

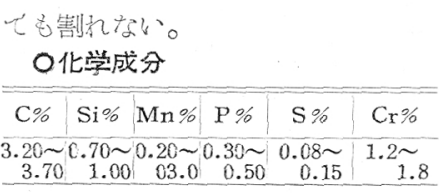

○機械的性梊

抗張力 $45 \mathrm{~kg} / \mathrm{mm}^{2}$

硬度 HRC 50〜52

(ステールボール仿 HRC 40

$\sim 50)$

硬落分布 (4” ボールの場合)

\begin{tabular}{|c|c|c|c|c|c|c|c|c|c|}
\hline 深さ & 表，面 & $5 \mathrm{~m} / \mathrm{m}$ & $1 \mathrm{~cm} / \mathrm{m}$ & $15 \mathrm{~m} / \mathrm{m}$ & $20 \mathrm{~m} / \mathrm{m}$ & $25 \mathrm{~m} / \mathrm{m}$ & $30 \mathrm{~m} / \mathrm{m}$ & $40 \mathrm{~m} / \mathrm{m}$ & 中 心 \\
\hline 硬度 & 52 & 52 & 52 & 52 & 51 & 51 & 51 & 50 & 50 \\
\hline \multicolumn{5}{|c|}{ 硬度差:こよる磨耗比 } & \multirow{4}{*}{\multicolumn{5}{|c|}{ 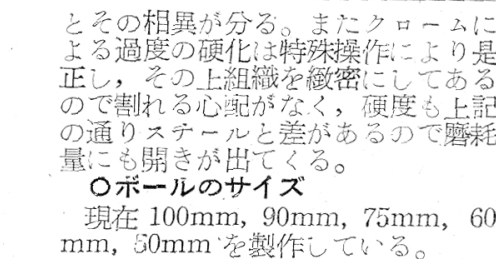 }} \\
\hline 硬 喥 & 50 & 45 & 40 & 35 & & & & & \\
\hline 磨耗比 & 1.0 & 1.2 & 1.4 & 1.9 & & & & & \\
\hline $\begin{array}{c}\text { 口物 } \\
\text { 破面 } \\
\text { - }\end{array}$ & 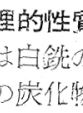 & 写 & $($ 炤) & n & & & & & \\
\hline
\end{tabular}

るから他のテルドボールと比较する

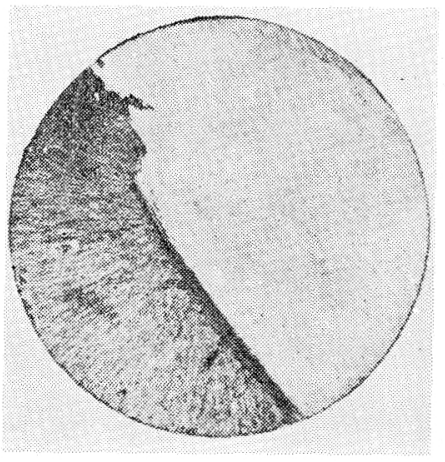

（古河鉱棠足尾製作所提供）

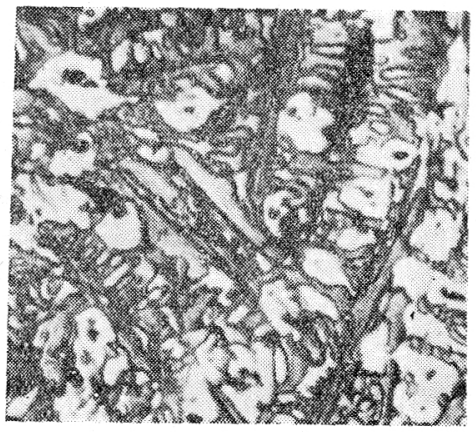

